\title{
The spatial penetration of Airbnb in the main tourist cities of Spain: Extent and Determinants
}

\author{
Nachatter Singh Garha \\ Centre d'Estudis Demogràfics \\ nsingh@ced.uab.es
}

\author{
Received: November 2020 \\ Accepted: April 2021 \\ Published: September 2021
}

\begin{abstract}
Uneven spatial distribution of rented accommodation offered on Airbnb has potential to create spatial inequalities in host cities. In this regard, the claim of the proponents of Airbnb that 'it increases spatial equality in the cities by creating opportunities for the house-owners in peripheral areas' requires scientific analysis and empirical evidence. Using the data obtained from the Inside Airbnb website, 2011 census, the municipal register of Spain and OpenStreetMap, this article first measures the degree of penetration and spatial clustering (with LISA statistics) of the Airbnb listings in seven main tourist cities of Spain (Barcelona, Madrid, Valencia, Seville, Mallorca and Malaga). Second, it analyses (with multiple linear regression models) the spatial, socio-economic, demographic and cultural determinants of the spatial clustering of accommodation offered on Airbnb in the selected cities; and finally, it compares the growth of Airbnb and its impact on spatial inequalities in the selected cities.
\end{abstract}

Keywords: Airbnb; tourist cities; spatial analysis; determinants; Spain

Resum. La penetració espacial d'Airbnb a les principals ciutats turistiques d'Espanya: extensió $i$ determinants

La desigual distribució espacial dels allotjaments llogats que s'ofereixen a Airbnb té el potencial de crear desigualtats espacials a les ciutats amfitriones. En aquest sentit, l'afirmació dels defensors d'Airbnb que «augmenta la igualtat espacial a les ciutats en crear oportunitats per als propietaris d'habitatges a les zones periferiques» requereix una anàlisi científica i evidències empíriques. Utilitzant les dades obtingudes de la pàgina web Inside Airbnb, del cens de 2011, del padró municipal d'Espanya i d'OpenStreetMap, aquest article mesura, en primer lloc, el grau de penetració i d'agrupament espacial (amb estadístiques LISA) de les llistes d'Airbnb en set de les principals ciutats turístiques d'Espanya (Barcelona, Madrid, València, Sevilla, Mallorca i Màlaga); en segon lloc, analitza (amb múltiples models de regressió lineal) els determinants espacials, socioeconòmics, demogràfics i culturals de l'agrupació espacial dels allotjaments oferts a Airbnb a les ciutats seleccionades; i finalment, compara el creixement d'Airbnb i el seu impacte en les desigualtats espacials a les ciutats seleccionades.

Paraules clau: Airbnb; ciutats turístiques; anàlisi espacial; determinants; Espanya 
Resumen. La penetración espacial de Airbnb en las principales ciudades turísticas de España: extensión y determinantes

La desigual distribución espacial de los alojamientos alquilados que se ofrecen en Airbnb tiene el potencial de crear desigualdades espaciales en las ciudades anfitrionas. En este sentido, la afirmación de los defensores de Airbnb de que "aumenta la igualdad espacial en las ciudades al crear oportunidades para los propietarios de viviendas en las zonas periféricas» requiere un análisis científico y evidencias empíricas. Utilizando los datos obtenidos del sitio web Inside Airbnb, del censo de 2011, del padrón municipal de España y de OpenStreetMap, este artículo mide, en primer lugar, el grado de penetración y de agrupamiento espacial (con estadísticas LISA) de los listados de Airbnb en siete de las principales ciudades turísticas de España (Barcelona, Madrid, Valencia, Sevilla, Mallorca y Málaga); en segundo lugar, analiza (con múltiples modelos de regresión lineal) los determinantes espaciales, socioeconómicos, demográficos y culturales de la agrupación espacial de los alojamientos ofrecidos en Airbnb en las ciudades seleccionadas; y finalmente, compara el crecimiento de Airbnb y su impacto en las desigualdades espaciales en las ciudades seleccionadas.

Palabras clave: Airbnb; ciudades turísticas; análisis espacial; determinantes; España

Résumé. La pénétration spatiale d'Airbnb dans les principales villes touristiques d'Espagne: extension et déterminants

Une répartition spatiale inégale des logements loués proposés sur Airbnb peut créer des inégalités spatiales dans les villes hôtes. À cet égard, l'affirmation des partisans d'Airbnb selon laquelle «Airbnb accroît l'égalité spatiale dans les villes en créant des opportunités pour les propriétaires des zones périphériques » nécessite une analyse scientifique et des preuves empiriques. À partir des données obtenues du site Web Inside Airbnb, du recensement de 2011, du registre municipal d'Espagne et d'OpenStreetMap, cet article mesure d'abord le degré de pénétration et de clustering spatial (avec les statistiques LISA) des annonces Airbnb dans sept principales villes touristiques d'Espagne (Barcelone, Madrid, Valence, Séville, Majorque et Malaga). Ensuite, il analyse (avec de multiples modèles de régression linéaire) les déterminants spatiaux, socio-économiques, démographiques et culturels du regroupement spatial des hébergements proposés par Airbnb dans les villes sélectionnées. Enfin, il compare la croissance d'Airbnb et son impact sur les inégalités spatiales dans les villes sélectionnées.

Mots-clés : Airbnb ; villes touristiques; analyse spatiale; déterminants ; Espagne

\section{Summary}
1. Introduction
4. Results
2. Literature review
5. Concluding remarks
Bibliographical references

3. Data Sources and Methodology 


\section{Introduction}

Airbnb is a hospitality service that allows people to rent their unused rooms or entire apartments through computer-mediated transactions. It originated in 2008 in the United States and since then it has expanded to 100,000 cities in 191 countries and regions worldwide (Airbnb, 2019). In October 2019, it had more than 7 million listings worldwide and on average over 2 million people were staying on Airbnb per night (Ibid). It is not the only short-term rental service in the market; however, it is certainly the largest service with approximately twice as many listings as its nearby competitors (HomeAway, Houset etc.). Its success is apparent from the fact that it generates more annual revenue (around $\$ 38$ billion) than the most famous hotel chains, such as Hilton and Marriott International (Molla, 2019). Initially, it began with the idea of renting spare rooms in private homes as a way to generate extra income, but now it has become an actual alternative to traditional accommodation (Larpin et al., 2019). In the last decade, "it has shifted from being a niche product (for young people or experienced tourists seeking a lodging type more integrated in the local community) to being a conventional product open to mass demand" (Mínguez et al., 2019: 5). The company's mission, as described by the company, is "to create a world where people can belong through healthy travel that is local, authentic, diverse, inclusive and sustainable. Airbnb uniquely leverages technology to economically empower millions of people around the world to unlock and monetize their spaces, passions and talents and become hospitality entrepreneurs". (Airbnb, 2019). It presents a very positive image of the company, which acts as a bridge to connect people worldwide and allow them to share their houses and neighbourhoods.

Airbnb has created a new category of rental housing, i.e. short-term rentals, which occupies a lacuna between traditional residential rental housing and hotel accommodation (Wachsmuth and Weisler, 2018). The proponents of Airbnb claim that these services have made it easier and more lucrative for small house-owners to rent their spare rooms, which supplements their monthly income and brings tourism to neighbourhoods which tourists traditionally do not visit (Gunter, 2018). According to them, it empowers people to exploit the full potential of their properties and generates additional income for businesses in these neighbourhoods. However, critics claim that these services take away already scarce long-term rental housing units in cities, increase rents for long-term rentals (Horn and Merante, 2017; Boros et al., 2018), transform the residential buildings into commercial assets, which are often bought by foreign investors to put in the short-term rentals business (Cócola Gant and Gago, 2019), adversely affect the hotel business (Zervas et al., 2014; Guttentag, 2015), displace the native population from their traditional neighbourhoods (Samaan, 2015; Wachsmuth et al., 2017; Wieditz, 2017; Lee, 2016) and intensify the process of gentrification (Ioannides et al., 2018; Gravari-Barbas and Guinand, 2017). Moreover, Airbnb's business model has been controversial since its inception, as it ignores the rules and 
regulations of housing and land use in almost every city where it operates (Wachsmuth and Weisler, 2018).

Airbnb listings are unevenly distributed in the host cities due to the location of different spatial factors, such as tourist attractions, historical monuments, business centres and sports venues. The concentration of Airbnb listings in certain specific neighbourhoods of big tourist cities also directs the flow of revenue earned in the form of rent or the profits made by local businesses through tourism-related sales and services to these neighbourhoods. It creates spatial inequalities and problems emerging from over-crowding in specific areas of tourist cities (Quattrone et al., 2016) that often have a large disparity between the rich and the poor and over-utilized public services. The rapid conversion of long-term rental residential buildings in working-class neighbourhoods into commercial tourist apartments through Airbnb exacerbates the problems of the local poor population, which is eventually displaced from its traditional neighbourhoods by the rich tourist class (Cócola Gant, 2016).

As Airbnb provides accommodation to short-term visitors, the cities that receive a large number of tourists are best suited to its business model. In Spain, tourism is one of the most important economic activities in many coastal and historic cities. During the last decade, all major tourist cities in Spain have witnessed an unprecedented growth of Airbnb. In previous research, several authors have discussed the impact of Airbnb on the tourism and hotel industry (Gutiérrez et al., 2017), housing market (Garcia-López et al., 2019), quality of life in the city (Cócola Gant, 2016; Cócola Gant and Gago, 2019), the commercialization of residential units (Lestegás et al., 2019), and the gentrification of city centres (Yrigoy, 2017, 2019). Some authors have used spatial analysis techniques to study the impact of Airbnb in other European cities (Gunter and Önder, 2017; Boros et al., 2018; Domènech et al., 2019). In Spain, some studies have attempted to do this at a national level (Adamiak et al., 2019); however, the spatial penetration of Airbnb listings in different neighbourhoods of the main tourist cities and the factors that determine it at the census tract level have not yet been studied. This paper responds to these questions with empirical evidence from seven main tourist cities of Spain that allows us to understand the geographical logic behind the distribution of Airbnb accommodation and its impact on spatial inequalities. Therefore, the main objectives of this paper are: first, to analyse the spatial penetration of Airbnb in seven main tourist cities of Spain: Madrid, Barcelona, Valencia, Seville, Malaga, Palma de Mallorca and Bilbao, which have the highest number of Airbnb listings and receive the most tourists (both national and international) in Spain; second, to analyse the spatial, structural, demographic and cultural factors that determine the degree and location of spatial clustering of the accommodation offered on Airbnb; and third, to compare the extent of the spatial penetration of Airbnb and its main determinants in the selected cities.

The paper is structured as follows: first, a literature review is presented, which provides a strong basis for the formulation of the initial hypotheses that are tested in this study. In the next section, data sources and methodology 
used in the paper are explained. Then, the results of the spatial analysis and the regression models are presented. Finally, a discussion on the impact of Airbnb on the tourist cities and some conclusions are offered.

\section{Literature review}

Over the last decade, the sharing economy has witnessed remarkable growth, especially in the transportation (BlaBlaCar, Uber) and tourist accommodation (Airbnb, Homeaway, Houset and Onlyap) sectors (Fraiberger and Sundararajan, 2015; Forno and Garibaldi, 2015). In short-term rentals, Airbnb has become the leading service provider worldwide. Consequently, a large number of researchers have studied the Airbnb phenomenon from different perspectives: economic, legal, urban and spatial.

From an economic perspective, Airbnb is considered as an unfair competitor compared to other types of tourist accommodation, such as hotels, hostels or pensions (Oskam and Boswijk, 2016). There is no consensus among researchers about the impact of Airbnb on the hotel industry. In their studies, Zervas et al. (2014) and Dogru et al. (2018) found that the increase in the supply of Airbnb listings has a negative effect on the average daily price and occupancy rates of the hotel rooms in the US cities. Contrarily, Choi et al. (2015) and Varma et al. (2016) found that the presence of Airbnb does not influence hotel performance; rather, both are complementary. More recently, Heo et al. (2019), in their study of Airbnb in Paris, concluded that consumers consider Airbnb as an alternative to hotels that provides accommodation at a relatively cheaper price, which negatively affects the demand for hotel rooms in the city. Apart from the hotel industry, the changing behaviour of tourists who prefer to share apartments with others than to rent a room in a hotel and the increasing number of hosts who want to rent their apartment to short-term visitors in place of long-term tenants has increased the potential of Airbnb to affect the traditional housing market in many tourist cities (Bulchand-Gidumal et al., 2019). Wachsmuth and Weisler (2018), in their study of New York City, explain how Airbnb generates a rent gap by replacing long-term rentals with short-term rentals in certain areas within the city, making long-term rentals unaffordable for local people. In their studies, Lee (2016) and Horn and Merante (2017) highlighted the role of Airbnb in exacerbating the availability and affordability of long-term rentals in Los Angeles and Boston. In Spain, Yrigoy (2019) has measured the rent gap created by Airbnb in Palma de Mallorca, which in turn contributed to the displacement of local people from the city centre. Similarly, a study conducted in the Canary Islands found that the areas with high Airbnb prices are also those with high supply of Airbnb accommodation, which shows a positive correlation between Airbnb prices and Airbnb supplies (Eugenio-Martin et al., 2019). As far as local businesses are concerned, Airbnb is also held responsible for increasing commercial gentrification through tourism and the replacement of traditional businesses for residents by franchised establishments that serve tourists (Blázquez-Salom, 2019). 
From a legal perspective, researchers have focused on the legal and regulatory aspects of the Airbnb service (Quattrone et al., 2018). Wachsmuth and Weisler (2018), in their study of US cities, highlighted that Airbnb does not follow the rules and regulations of the cities where it operates. From an urban perspective, studies have highlighted the social repercussions of Airbnb phenomena on urban populations, especially with respect to distortion of the real estate market, displacement of the native population from their traditional neighbourhoods and tourism-related gentrification of urban districts (Dudas et al., 2017). Some studies have presented Airbnb as a profitable business for both house-owners and tourists. It helps owners to rent their free rooms and earn some extra money, and at the same time, it helps tourists to find cheap rooms or entire apartments at their desired locations (Gunter, 2018). However, many researchers have explained Airbnb as an existential threat for many traditional working-class neighbourhoods in the main tourist cities (Fuentes and Navarrete, 2019). It is also held responsible for the collective displacement of the native population (Cócola Gant, 2016), which in turn leads to the gentrification of specific areas of the host cities (Novy, 2017; Ioannides et al. 2018).

Lastly, from a spatial perspective, previous studies have analysed the location of Airbnb listings at different scales (national, city or infra-municipal levels) and its relationship with other elements, such as tourism resources, socio-demographic profile of the resident population, housing market, cultural aspects and hotel offerings. Some researchers have studied the spread of Airbnb at the national level (Abdar and Yen, 2017; Cesarani and Nechita, 2017; Strommen-Bakhtiar and Vinogradov, 2019), while others have focused on the municipal or city level (Adamiak, 2018). In their study of eight US cities, Quattrone et al. (2018) found that Airbnb listings tend to be clustered in central neighbourhoods and in areas occupied by creative classes. In the European context, Airbnb listings have tended to concentrate in neighbourhoods that have undergone processes of commercial and tourist gentrification (Roelofsen, 2018). In their study of the spatial penetration of Airbnb in London, Quattrone et al. (2016) found that the growth of Airbnb started in central areas, as expected due to tourist demand, but then extended to the socio-economically deprived peripheral areas of the city. Dudas et al. (2017) showed the concentration of Airbnb offerings on the basis of population age, available housing stock and closeness of tourism resources in New York City. In their study, Domènech et al. (2019) showed the importance of the location of ski resorts and second homes in determining the spatial distribution of Airbnb in Switzerland. In Spain, Adamiak et al. (2019) studied the spatial distribution of Airbnb listings at national level. In Barcelona, Gutiérrez et al. (2017) showed a centre-periphery pattern of Airbnb distribution, in which, in the centre Airbnb competes with other tourist accommodation types, but in the periphery it complements the supply of short-term rentals. Similarly, Arias and Quaglieri (2016) showed a positive correlation between the presence of hotels and Airbnb penetration in different parts of Barcelona. Yrigoy (2017) 
found that the concentration of Airbnb listings is determined by the cultural heritage of the historic centre of Palma de Mallorca city.

In this context, this article aims to expand the existing knowledge on the spatial penetration of Airbnb by analysing the current spatial distribution of Airbnb accommodation at census tract level in seven main tourist cities of Spain and identifying the social, demographic, structural and cultural determinants behind the spread of Airbnb in these cities. My main hypotheses are:

H1. Airbnb listings are clustered in certain specific areas (city centres, historical monuments, sports venues and business districts) of the selected cities with a high presence of hotels, high population diversity, high average household income, large proportion of small and vacant apartments, and more educated population.

H2. Airbnb creates new or increases the existing spatial inequalities by concentrating the revenue earned in the form of rent or the profit earned by local business to serve the needs of tourists (bars, restaurants and gift shops) in certain specific areas of the selected cities.

\section{Data Sources and Methodology}

\subsection{Data Sources}

The Airbnb data were obtained from Murray Cox's website "Inside Airbnb". For this paper, I downloaded data of all Airbnb listings in seven main tourist cities of Spain in September 2019. I also verified the validity of the data by selecting random listings in each city and double-checking both their presence on the original Airbnb platform, and the accuracy of their locations. Each listing provides a large amount of information, including: host and room id, accommodation location, room type, geographic location, accommodation details, availability, price and number of reviews for each accommodation. The host id, which is a unique identification number for each host in Airbnb, is used to quantify the number of multi-hosts (hosts who rent more than 3 listings) in the selected cities. The high proportion of multi-hosts is considered as an indicator of the commercialization of the services of Airbnb, which was started as a sharing service for local residents. The selected cities vary substantially among each other in terms of size, number of census tracts, population, historical and cultural heritage, political and economic importance and number of Airbnb listings registered in 2019. However, all of them have two things in common, i.e. a large number of tourists received annually and a remarkable growth of Airbnb during the last decade (Table 1).

Airbnb started its business in Spain in 2009. Over the past decade, it has penetrated the residential areas of the traditional working-class neighbourhoods of all major cities of Spain. The recent global financial crisis (2008-2014) and the austerity measures adopted by the Spanish government facilitated the growth of Airbnb in Spain (Gil and Sequera, 2018). In 2019, Madrid, which 
Table 1. Descriptive statistics of the dependent variable segmented by census tracks in selected cities of Spain

\begin{tabular}{|c|c|c|c|c|c|c|c|}
\hline Spanish Cities & $\begin{array}{l}\text { Population } \\
\text { (in 2018) }\end{array}$ & $\begin{array}{c}\text { Tourists in } \\
2018 \\
\text { (in millions) }\end{array}$ & $\begin{array}{l}\text { Number of } \\
\text { Census Tracts }\end{array}$ & $\begin{array}{c}\text { Airbnb } \\
\text { listings (Sep. } \\
\text { s } \quad \text { 2019) }\end{array}$ & $\begin{array}{c}\text { Airbnb } \\
\text {. listings per } \\
\text { Census Tract }\end{array}$ & $\begin{array}{l}\text { Max. listings } \\
\text { in a Census } \\
\text { Tract }\end{array}$ & $\begin{array}{c}\text { Census Tracts } \\
\text { with } 0 \text { listings } \\
\text { (\%) }\end{array}$ \\
\hline Madrid & 3223334 & 7.12 & 2443 & 20837 & 9 & 270 & 15.26 \\
\hline Barcelona & 1620343 & 8.91 & 1068 & 20404 & 19 & 303 & 5.43 \\
\hline Valencia & 791413 & 2.06 & 596 & 7233 & 12 & 117 & 6.77 \\
\hline Seville & 688711 & 3.01 & 531 & 6284 & 12 & 259 & 25.42 \\
\hline Malaga & 571026 & 2.71 & 437 & 6051 & 14 & 285 & 18.67 \\
\hline Palma de Mallorca & 409661 & 10.67 & 252 & 1939 & 8 & 85 & 16.67 \\
\hline Bilbao & 345821 & 1.27 & 277 & 1151 & 4 & 42 & 22.23 \\
\hline
\end{tabular}

Source: Inside Airbnb (2019); Municipal register (2018); Statista (2019).

is the biggest city among those selected, had the highest number of Airbnb listings $(20,837)$, followed by Barcelona $(20,404)$ and Valencia $(7,233)$. Barcelona had the highest number of listings in a census tract, i.e. 303, with an average of 19 listings per census tract. Despite the rapid growth of Airbnb over the last few years, Seville (25.4\%) and Bilbao $(22.2 \%)$ had the highest share of census tracts without any Airbnb listings. Bilbao had the lowest average number (i.e. 4) of listings per census tract among the selected cities. In 2019, the Airbnb listings were concentrated in the historical downtown areas and business centres of the selected cities (Figure 1). These areas are already known for their tourist attractions and cultural heritage.

In order to explain the varying spatial penetration of Airbnb in selected cities, four different sets of variables are used: spatial, demographic, socio-economic and cultural (Table 2). All of these variables have been obtained from the 2011 Census of population and housing, continuous population register (Padrón Continuo), other municipal records in Spain and Open sources. The first three sources provide population and socio-economic data at census tract level, which is the smallest territorial unit of analysis available in Spain. OpenStreetMap, Google Maps, TripAdvisor and a variety of official city websites are used to download spatial data at the census tract level.

In the Spatial variables, I have included distance to city centre (dist), points of interest (poi), number of hotels available in a census tract (hotel) and access to transport services, i.e. bus or metro stops (trans) as explanatory variables. In previous studies, dist is considered as one of the most important determinants of the presence of Airbnb in an area (Quattrone et al., 2016). The places closer to the city centre are likely to have a higher number of Airbnb listings, and vice versa. For simplicity and homogeneity, the TripAdvisor website is used to identify the central points of all cities, which are: Puerta del Sol in Madrid, Plaza de Catalonia in Barcelona, Plaza de Don Federico Moyúa in Bilbao, Plaza de la Constitución in Malaga, Plaza Mayor in Palma de Mallorca, Plaza del Triunfo in Seville and Mainar Business Center in Valencia. For each city, dist is the shortest 
Figure 1. Total population and number of Airbnb listings in selected cities of Spain

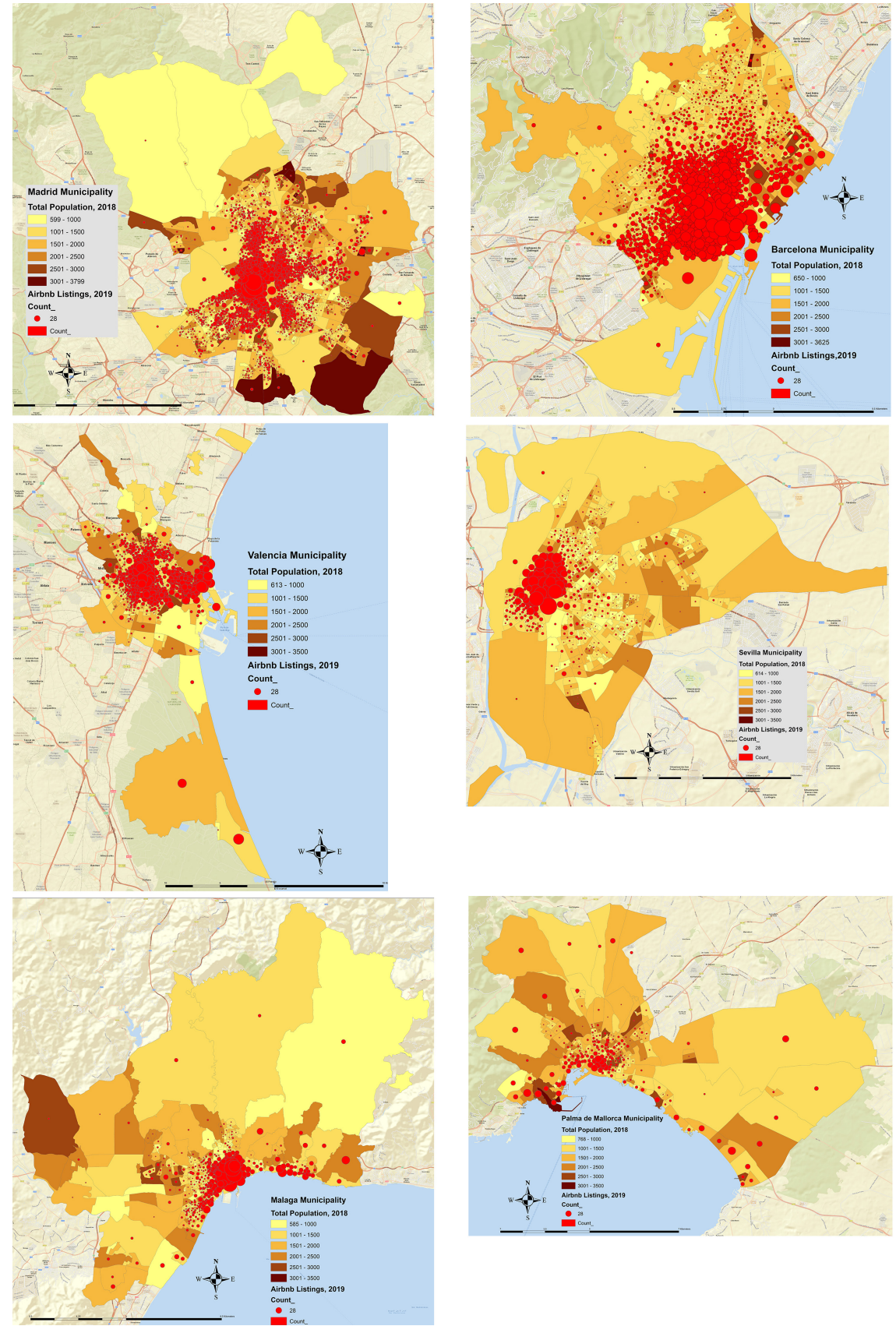

Source: Inside Airbnb (2019); Continuous Population Register (Padrón Continuo) (2018). 
Figure 1. Total population and number of Airbnb listings in selected cities of Spain (continuation)
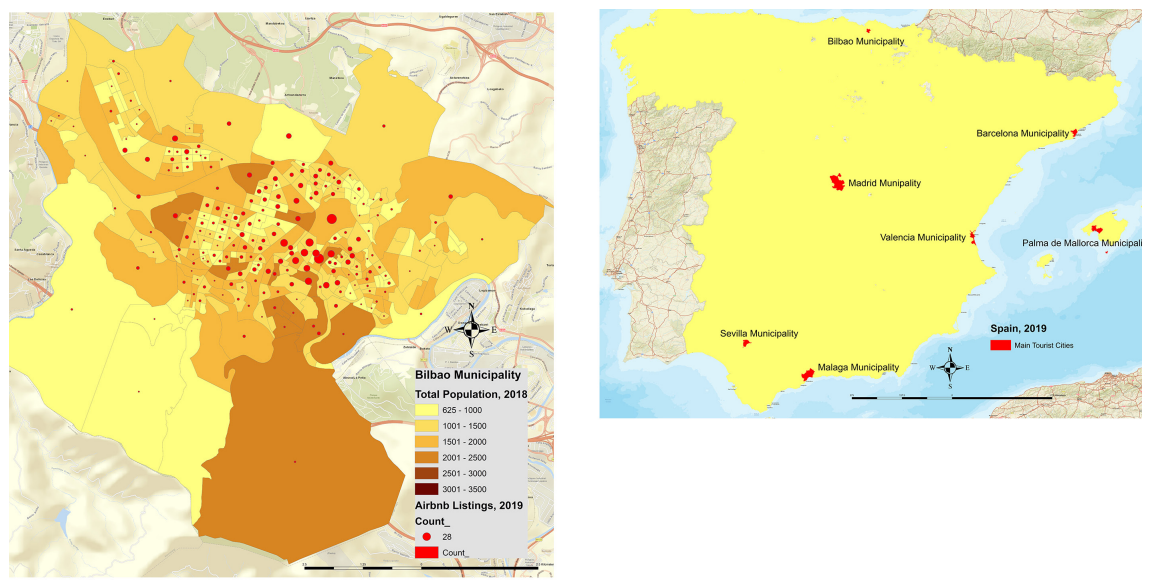

Source: Inside Airbnb (2019); Continuous Population Register (Padrón Continuo) (2018).

distance in metres between the central point and the centre of the census tract under study. The presence of poi (geographic features that might be of interest for tourists or short-term visitors, such as historical monuments, restaurants, town halls, post offices, cinemas, adventure parks, stadiums, etc.) in an area is expected to increase its tourist appeal and the number of Airbnb offerings in that area. OpenStreetMap data are used to count the number and find the location of poi in all census tracts. The latitude/longitude coordinates for all poi that fall under the following Open Street Map categories: accommodation, attractions, eating and drinking, retail and sports, and entertainment for each selected city are extracted. The availability of hotels in an area is considered an indicator of the potential tourism attraction of that area. The data about the number and geographical location (latitude-longitude) of hotels in all cities were downloaded from Open Street Map, following the categories: hotel, bread and breakfast, motel and pension. Finally, in the spatial variables, easy access to public transport is also considered to increase the number of Airbnb listings in a given area. Normally, tourists or other short-term visitors prefer to stay in areas that are well-connected with public transport to save money and time. This concentrates the Airbnb listings around the metro lines or bus stops. Open Street Map is used to count the number and geographical location of metro and bus stops available in each census tract of the selected cities.

In the demographic variables, I have used population density ( $p o p d e n$ ), proportion of young people from 20-34 years old (young), proportion of residents born in the municipality (native), and proportion of single-person households in a given area of the selected cities (singleph). The popden is calculated by dividing the number of people living in a census tract by its surface area. In previous studies, high population density is considered to have a crucial impact 
Table 2. Explanatory variable used in this article

\begin{tabular}{|c|c|c|c|c|}
\hline Category & Acronym & Metric & Source & Description \\
\hline Airbnb & $a b n b$ & Airbnb penetration & Airbnb Website, 2019 & Airbnb listings in the city \\
\hline \multirow[t]{4}{*}{ Spatial } & dist & Distance to center & Google maps & $\begin{array}{l}\text { Distance from the center of the city } \\
\text { (in meters) }\end{array}$ \\
\hline & poi & Points of Interests & Trip Advisor & $\begin{array}{l}\text { Number of points of interest in a } \\
\text { census track }\end{array}$ \\
\hline & hotel & Hotels & Trip Advisor & Number of hotels in a census track \\
\hline & trans & Transport Access & Open street map & $\begin{array}{l}\text { Number of bus and metro stops in a } \\
\text { census track }\end{array}$ \\
\hline \multirow[t]{4}{*}{ Demographic } & popden & Population density & $\begin{array}{l}\text { Municipal Register, } \\
2018\end{array}$ & Population density in a census track \\
\hline & young & Age Structure & $\begin{array}{l}\text { Municipal Register, } \\
2018\end{array}$ & $\begin{array}{l}\text { People aged between } 20 \text { and } 34 \\
\text { years }(\%)\end{array}$ \\
\hline & native & Native population & $\begin{array}{l}\text { Municipal Register, } \\
2018\end{array}$ & Residents born in a census track (\%) \\
\hline & singlephh & Household structure & Census, 2011 & $\begin{array}{l}\text { Single person household in } \\
\text { a census track }(\%)\end{array}$ \\
\hline \multirow[t]{5}{*}{ Socioeconomic } & ahincome & $\begin{array}{l}\text { Average household } \\
\text { income }\end{array}$ & INE, 2016 & $\begin{array}{l}\text { Average household income } \\
\text { in a spatial unit }\end{array}$ \\
\hline & houserent & Average house rent & $\begin{array}{l}\text { INCASOL/idealista, } \\
2019\end{array}$ & $\begin{array}{l}\text { Average house rent (Euros/square } \\
\text { meter) }\end{array}$ \\
\hline & housesize & Size of Apartments & Census, 2011 & $\begin{array}{l}\text { Apartments below } 60 \text { square meters } \\
\text { size }(\%)\end{array}$ \\
\hline & housevac & Unoccupied Apartments & Census, 2011 & Vacant apartments (\%) \\
\hline & owner & Tenancy regime & Census, 2011 & Owner-occupied residences (\%) \\
\hline \multirow[t]{2}{*}{ Cultural } & education & Level of education & Census, 2011 & People with university education (\%) \\
\hline & mig & $\begin{array}{l}\text { International } \\
\text { Migration }\end{array}$ & $\begin{array}{l}\text { Municipal Register, } \\
2018\end{array}$ & $\begin{array}{l}\text { Immigrants from high HDI countries } \\
(\%)\end{array}$ \\
\hline
\end{tabular}

Source: Compiled by author.

on the spread of sharing economy services (Fraiberger and Sundararajan, 2015; Quattrone et al., 2016). The variable young, which shows the age structure of the resident population in different neighbourhoods, is also expected to have a significant impact on the penetration of Airbnb. The neighbourhoods with a high proportion of young population are more likely to have a higher number of Airbnb listings compared to other neighbourhoods with a high share of older population, especially due to the greater use of modern technology among the younger population (Florida, 2002). The variable native has tended to have a significant influence on the socio-economic configuration of the specific neigh- 
bourhoods, which in turns affects the number of listings in these neighbourhoods. In previous studies, the areas with a high proportion of native population have been shown to have a small number of Airbnb listings (Quattrone et al., 2016). Lastly, the variable singleph is also expected to facilitate the spread of Airbnb, since it is more feasible for a single person to share spare rooms of their apartment, which for a family household can be a difficult choice.

In the socio-economic variables, I have included the average household income (ahincome), average house-rent (houserent), average house-size (housesize), the proportion of vacant apartments (vachouse) and the tenancy regime (owner) as explanatory variables. The areas with a high proportion of low average income households are expected to have less Airbnb listings, since tourists and other short-term visitors normally try to avoid socio-economically vulnerable places in the host cities. The areas with high house-rent are expected to have more Airbnb listings, as this compels people to share their spare rooms to cover monthly expenses. The areas with a high proportion of small apartments (less than $60 \mathrm{~m}^{2}$ ) are less likely to have high penetration of Airbnb. The small size of an apartment leaves no spare rooms to rent on Airbnb. A high proportion of vacant apartments is considered to have a positive impact on the penetration of Airbnb, by increasing the supply of accommodation that can be rented on Airbnb. Lastly, a high proportion of rented apartments in an area shows its potential as a good market for rental accommodation, which suits Airbnb's business model. In addition, the people who have rented an apartment for a long stay are more likely to share their apartment with short-term visitors, compared to house-owners, who use them as their principal residence.

In the cultural variables, I have used the proportion of people with university degrees (education) and the proportion of people who have immigrated from high Human Development Index countries (mig). These variables are used as a proxy to examine the access of population to modern technology, social media sites and the sharing economy in different parts of the selected cities. The high proportion of more educated people and the people immigrating from high HDI countries is expected to positively affect the penetration of Airbnb in selected cities, and vice versa.

\subsection{Methodology}

In order to measure the level of spatial penetration of Airbnb (clustering) in the selected cities of Spain, the Local Indicator of Spatial Association (LISA) ${ }^{1}$ index, which can be seen as the local equivalent of Moran's I (Anselin, 1995), is applied. The variable 'number of Airbnb listings in census tracts' is used to perform this analysis. Since the data are available at the census tract level, the

1. As an operational definition, LISA is any statistic that satisfies two requirements: first, the LISA for each observation gives an indication of the extent of significant spatial clustering of similar values around that observation; second, the sum of LISAs for all observations is proportional to a global indicator of spatial association. 
unit of spatial analysis will be the census tract. The local value of a LISA is computed as:

$$
I_{i}=\frac{\sum_{j=1}^{n} W i j\left(z_{i}-\bar{z}\right)\left(z_{j}-\bar{z}\right)}{s_{z}^{2} \sum_{j=1}^{n} W i j}
$$

Following the first law of geography that "everything is related to everything else, but near things are more related than distant things" (Tobler, 1970: 236), it is hypothesized that those census tracts with a higher or lower number of Airbnb listings will be clustered in certain areas of selected cities with similar attributes. The parameter for conceptualizing spatial relationships between census tracts was 'queen contiguity', which ensures that all the entities have a maximum possible number of neighbours in all directions. For each location, LISA values allow for the computation of its similarity with its neighbours and also for its significance to be tested. Five scenarios may emerge: first, locations with high values of Airbnb with similar neighbours (high-high), also known as 'hot spots'; second, locations with low values with similar neighbours (low-low), also known as 'cold spots'; third, locations with high values with low-value neighbours (high-low), potential 'spatial outliers'; fourth, locations with low values with high-value neighbours (low-high), potential 'spatial outliers'; and fifth, locations with no significant local autocorrelation.

Regression analysis has been carried out to identify the main determinants of the spatial penetration of Airbnb listings in the selected cities. Count data models (CDMs) have been applied (Cameron and Trivedi, 1998) because the dependent variable, the number of Airbnb listings by census tract in all selected cities, has a Poisson distribution (Figure 2). These models are especially useful when the events being analysed are recorded at a highly disaggregated territorial level and a significant number of spatial units have zero occurrence of dependent variable, a situation known as the 'zero problem'. However, the existence of census tracts with zero listings is relevant for our study, since it allows us to identify the independent variables that can explain the absence of Airbnb listings in certain areas of the selected cities. In our study, the number of census tracts in each selected city is large and in some census tracts zero Airbnb listings are reported (from the lowest of $5.4 \%$ in Barcelona to the highest of $25.42 \%$ in Seville), which justifies the use of CDMs. The spatial analysis performed (LISA indicator) has shown that there is a high spatial clustering of Airbnb listings in specific areas of selected cities. Therefore, to solve the problem of over dispersion and zero-inflation, a negative binomial regression model (NBM) has been applied. With a view to the general features of this estimation procedure, NBM assumes between-subject heterogeneity and that the process is the same for both zero and non-zero counts (Domènech et al., 2019). The choice of 
Figure 2. Density plot of the dependent variable (Airbnb listings) for all selected cities
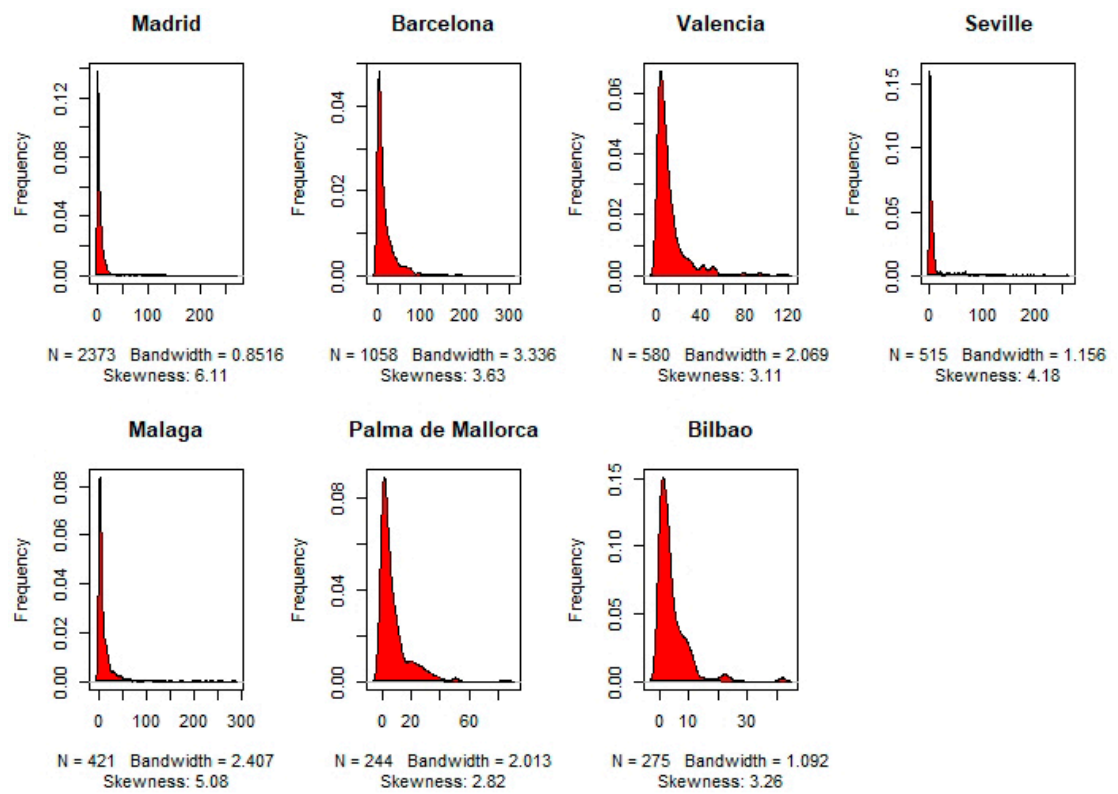

Source: Compiled by author.

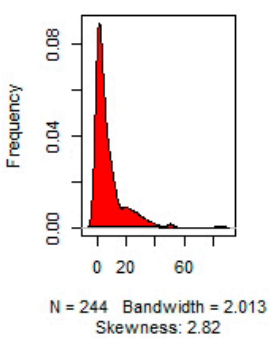

model has been supported by the results from the goodness of fit indicators, i.e. AIC and BIC.

Taking the census tract as a statistical unit and the number of Airbnb listings per census tract as dependent variable, two general non-linear NBM have been applied (Mccullagh and Nelder, 1989: 373). All the variables shown in Table 2 have been included as explanatory variables. Correlation among them has been checked (Figure 3) and multicollinearity (Cameron and Trivedi, 2005) has also been controlled with satisfactorily low values of the variance inflation factors (VIF). Following the previous studies, the threshold for VIF was set at 4 (Pan and Jackson, 2008; Rogerson, 2001).

Some of the explanatory variables have shown high correlation with each other. Therefore, to solve the problem of multicollinearity, two regression analyses have been implemented for all selected cities. In the first model, all variables are included, but in the second model, one of the explanatory variables (in the pair of highly correlated variables) has been excluded. This ensures that we correctly capture the effect of each independent variable on the dependent variable. It also allows us to see which model presents better goodness of fit indicators. The regression models are formulated as:

$$
\begin{gathered}
(E(Y))=\beta_{0}+\beta_{\text {x... }} \mathrm{Y}: \mathrm{NB}(\mu(\mathrm{x}<), \mathrm{k}) \\
\text { where }(x)=\mu(x) \text { and } V(x)=\mu(x)+k \mu x^{2}
\end{gathered}
$$


Figure 3. Correlation among explanatory variables for the main tourist cities of Spain
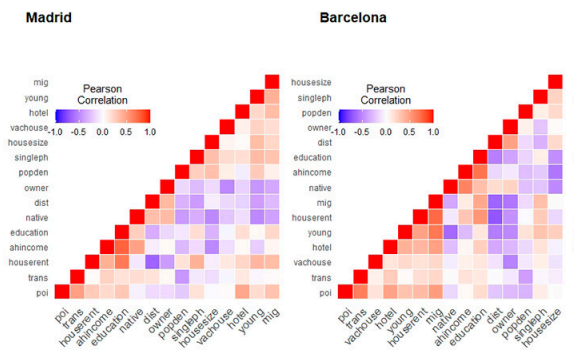

Valencia

Seville
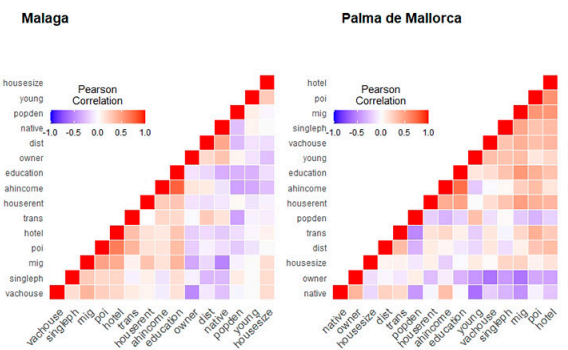

Bilbao
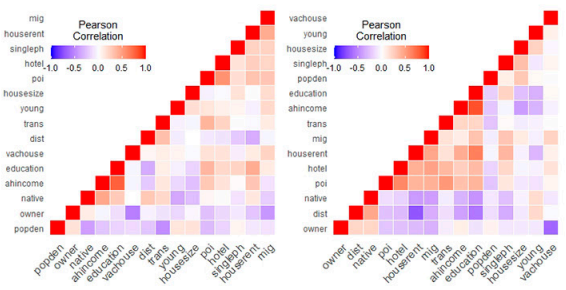

Source: Compiled by author.

(where $\beta_{0}$ is the intercept and $\beta_{x}$ is the regression coefficient vector of all covariates at the census tract level.

\section{Results}

\subsection{Spatial clustering of the Airbnb listings}

The high values of LISA indicators demonstrate the spatial clustering of the Airbnb accommodation in different parts of the selected cities in Spain (Table 3). This proves our first hypothesis that the spatial penetration of the Airbnb listings is highly uneven in the selected cities. All cities have a highhigh cluster of Airbnb listings (red patch) in the historical centre of the cities, surrounded by low-low clusters (blue patches) in the peripheral areas, which show the high and low penetration of Airbnb listings in these areas of the selected cities (Figure 4).

Madrid has the highest value of Moran's I, i.e. 0.83, which shows the spatial clustering of Airbnb listings in the city centre. In Madrid, the central neighbourhoods of Embajadores, Universidad, Palacio, Sol, Justicia and Cortes had $46.8 \%$ of the total listings in 2019 . These neighbourhoods have significant historical monuments, business houses, tourist attractions and government offices that attract a large number of short-term visitors and tourists. However, the peripheral neighbourhoods of El Plantio, Pavones, Valdemarin, Atalaya, El 
Table 3. Average value of Airbnb listings per census tract per cluster and the value of Moran's I in the main tourist cities of Spain

\begin{tabular}{lrrrrrrr}
\hline Spanish Cities & \multicolumn{1}{c}{ No Sig. } & \multicolumn{1}{c}{ High-High } & \multicolumn{1}{c}{ Low-Low } & Low-High & High-Low & \multicolumn{1}{c}{ Total } & Moran's I \\
\hline Madrid & $5.91(235)$ & $36.04(389)$ & $2.21(1458)$ & $4.67(295)$ & $12.56(66)$ & $8.53(2443)$ & 0.83 \\
Barcelona & $17.37(147)$ & $57.36(236)$ & $5.08(611)$ & $12.47(55)$ & $25.32(19)$ & $19.06(1068)$ & 0.79 \\
Valencia & $8.99(197)$ & $36.18(116)$ & $3.37(207)$ & $7.25(69)$ & $14.57(7)$ & $12.23(596)$ & 0.70 \\
Seville & $3.16(96)$ & $71.86(72)$ & $1.21(279)$ & $5.89(83)$ & $20(1)$ & $11.83(531)$ & 0.79 \\
Malaga & $6.67(156)$ & $62.01(70)$ & $2.47(175)$ & $7.22(27)$ & $16.83(6)$ & $13.89(434)$ & 0.76 \\
Palma de Mallorca & $11.0(62)$ & $24.81(27)$ & $1.96(141)$ & $5.0(1)$ & $14.57(21)$ & $7.69(252)$ & 0.51 \\
Bilbao & $2.61(104)$ & $11.33(61)$ & $0.88(64)$ & $2.47(34)$ & $8.2(5)$ & $4.16(277)$ & 0.49 \\
\hline
\end{tabular}

Source: Compiled by author.

Figure 4. Map of local Moran's spatial autocorrelation indicator with the variable Airbnb listings per census tract in all selected cities
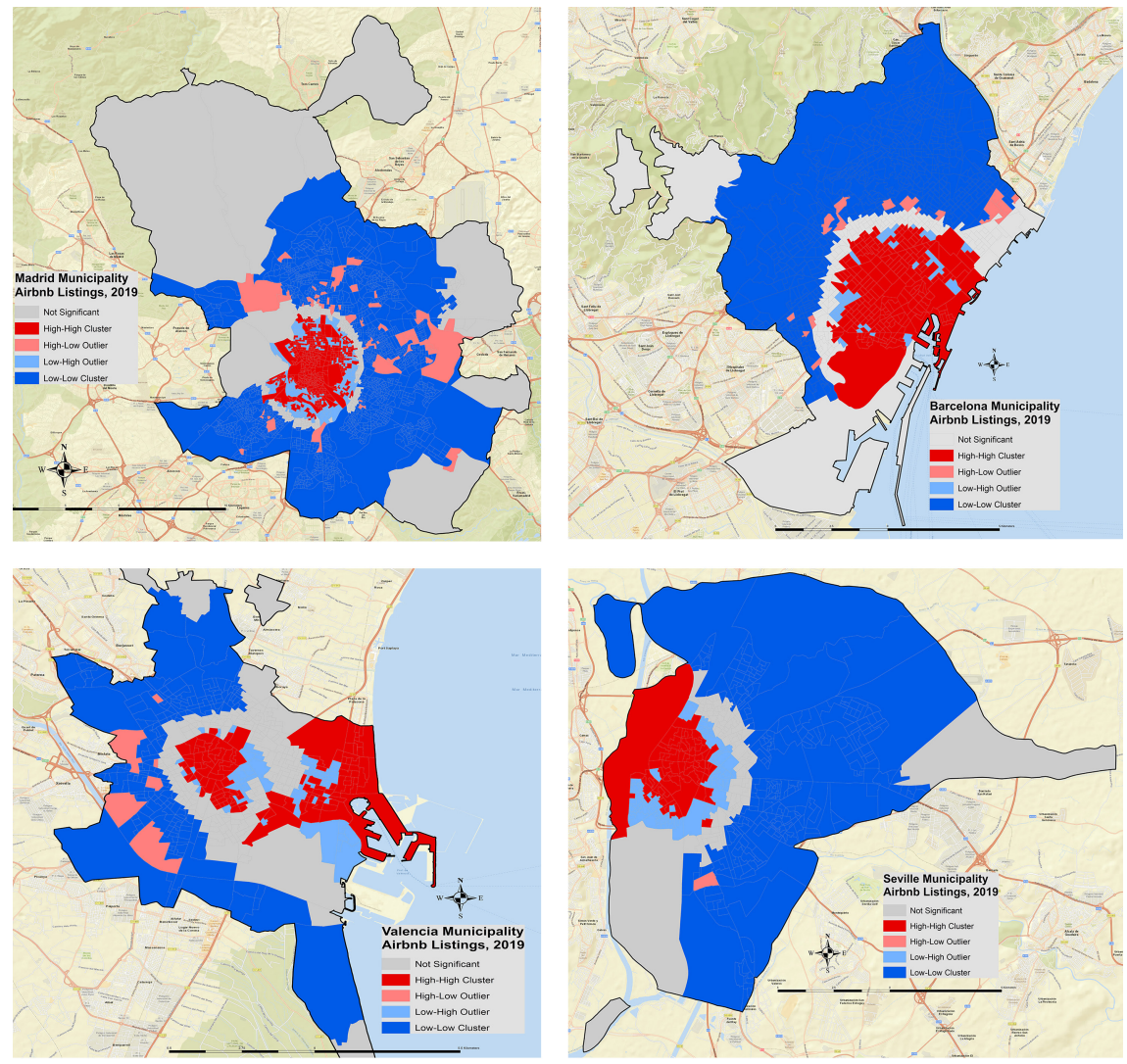

Source: Inside Airbnb. 
Figure 4. Map of local Moran's spatial autocorrelation indicator with the variable Airbnb listings per census tract in all selected cities (continuation)
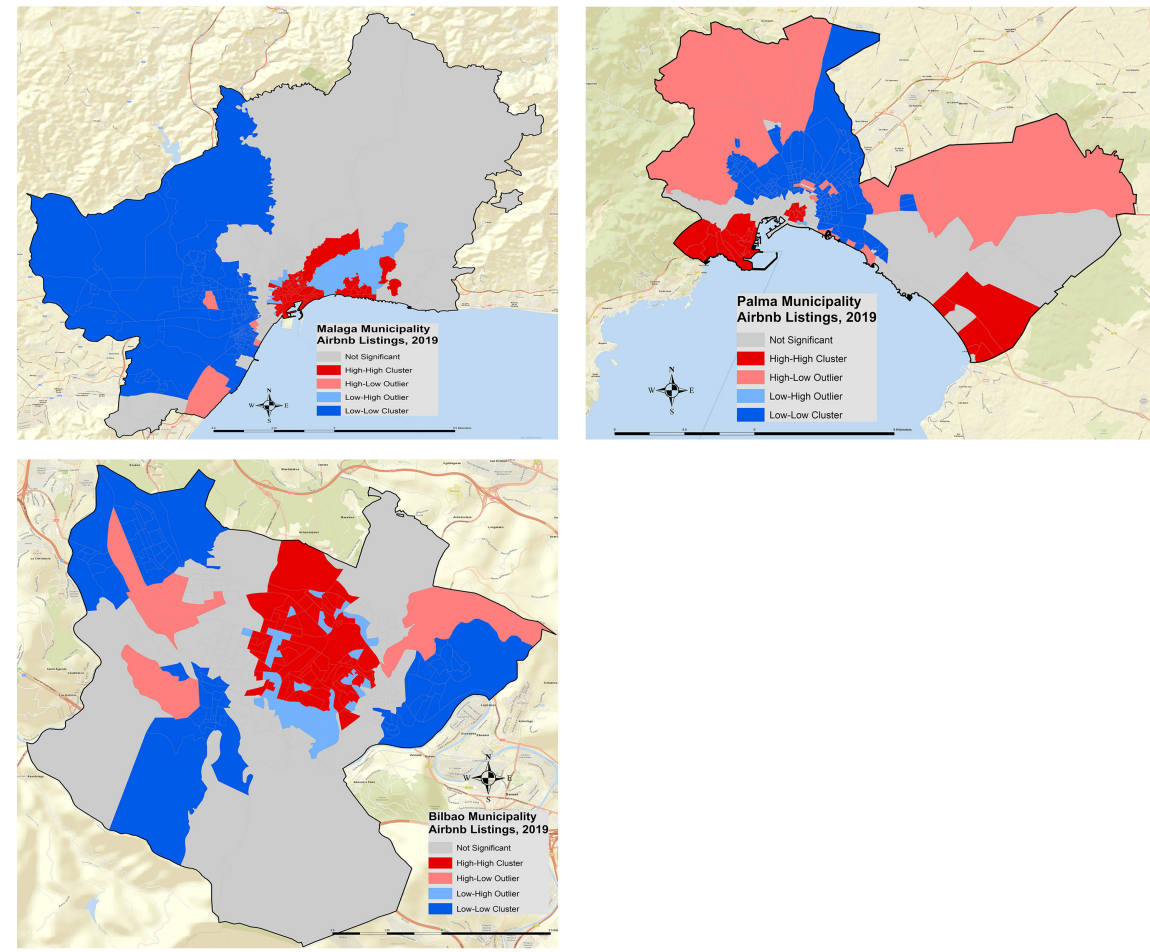

Source: Inside Airbnb.

Pardo, Fuentelareina and Horcajo had below 5 listings in each of them. They make up a low-low cluster that surrounds the city centre. The most socioeconomically vulnerable neighbourhoods of San Cristobal, Villaverde and Los Cármenes in Madrid had very few listings. After Madrid, Barcelona registered the second largest value of Moran's I, i.e. 0.79. In Barcelona, the central neighbourhoods of La Dreta de l'Eixample, El Raval, El Barri Gotic, Sant Pere, Santa Caterina i la Ribera, El Poble Sec, L'Antiga Esquerra de l'Eixample, La Sagrada Familia, La Vila de Gràcia and Sant Antoni accounted for $58.69 \%$ of the total listings in 2019. All these neighbourhoods form a very big high-high cluster in the historical centre and coastal areas of the city. These neighbourhoods have a large number of historical monuments, religious places, business houses and government offices that attract a large number of short-term visitors each year. At the same time, the peripheral neighbourhoods of La Trinitat Nova, Ciutat Meridiana, Canyelles, Torre Baró, Can Peguera, Baró de Viver, La Clota and Vallbona had below 10 Airbnb listings in each neighbourhood. These neighbourhoods form a low-low cluster in the northwest of the city. 
Valencia also registered a very high value of Moran's I, i.e. 0.70. Here, the central, historic and coastal neighbourhoods of Cabanyal-Canyamelar, Russafa, Sant Francesc, El Carme, El Mercat, La Malva-Rosa and La Seu had $38.3 \%$ of the total listings in 2019 . These neighbourhoods also own big business houses, public offices and are traditionally famous destinations for national and international tourists. On the contrary, the peripheral neighbourhoods of Mahuella-Tauladella, Les Cases de Barcena, Rafalell, Vistabella, Benifaraig and Borboto had below 5 Airbnb listings each. Seville, with a Moran's I value of 0.79 , is the third city in terms of the spatial clustering of Airbnb listings in Spain. In Seville, the central neighbourhoods of Alfalfa, Feria, Arenal, Santa Cruz, San Bartolome, Encarnacion-Regina and Triana Casco Antiguo had 46.9\% of the total listings in 2019. All these neighbourhoods are famous for their cultural heritage and historical monuments, making them perfect destinations for tourists. On the contrary, the neighbourhoods of Los Arcos, Las Naciones, Parque Atlantico, Las Dalias, Villegas, Zodiaco, Los Carteros and La Corza had no presence of Airbnb. Seville has the highest average number of listings in high-high clusters (i.e. 72), showing the high concentration of Airbnb listings in the central areas of the city.

Malaga, with a Moran's I value of 0.76 , had high spatial clustering of Airbnb listings in its downtown city centre. The neighbourhoods of Centro Histórico (20.1\%), La Merced, La Trinidad, La Goleta, El Ejido, La Malagueta, and Ensanche Centro had $47.7 \%$ of the total listings and form a high-high cluster in the historic central part of Malaga. Of the total 417 neighbourhoods in Malaga, 38\% had no Airbnb listings and 70.6\% had below 5 listings per neighbourhood. It had the second highest average number of listings in its high-high cluster (i.e. 62). The most socio-economically vulnerable neighbourhoods of Malaga, i.e. La Palma, La Palmilla, La Rosaleda, Martiricos, El Bulto, Herrera Oria, Sagrada Familia, Los Naranjos and Las Flores, had a very small number of Airbnb listings. Palma de Mallorca, with a Moran's I value of 0.51 , also had some spatial clustering of Airbnb listings in the central historic part of the city. The neighbourhoods of Puig Sant Pere, Jaume III, Llotja-born, Sant Jaume, Sant Nicolau, Plaça Patins and Cort had 46.3\% of the total listings in 2019. On the contrary, the La Indiotería, La Indiotería rural, Amanecer, Son Caldera and L'Olivera neighbourhoods had below 5 Airbnb listings in each of them. The most socio-economically vulnerable neighbourhoods of La Soledad, Son Gotleu, Son Ximelis and Virgen de Lluc also had a very small number of Airbnb listings, which shows the concentration of Airbnb in socio-economically rich neighbourhoods of the city. Bilbao registered the lowest value of Moran's I, i.e. 0.49, which shows the lowest level of spatial clustering of Airbnb listings in the city. In Bilbao, the neighbourhoods of Abando, Ciudad Jardin, Uribarri, San Francisco, Castaños, Zabala and Amezola had $46.8 \%$ of the total listings in the city, forming a high-high cluster in the north of the city. Among the selected cities, it had the minimum number of average listings in the high-high cluster (i.e. 11). 
Figure 5. Types of hosts and their share in total listings in 2019

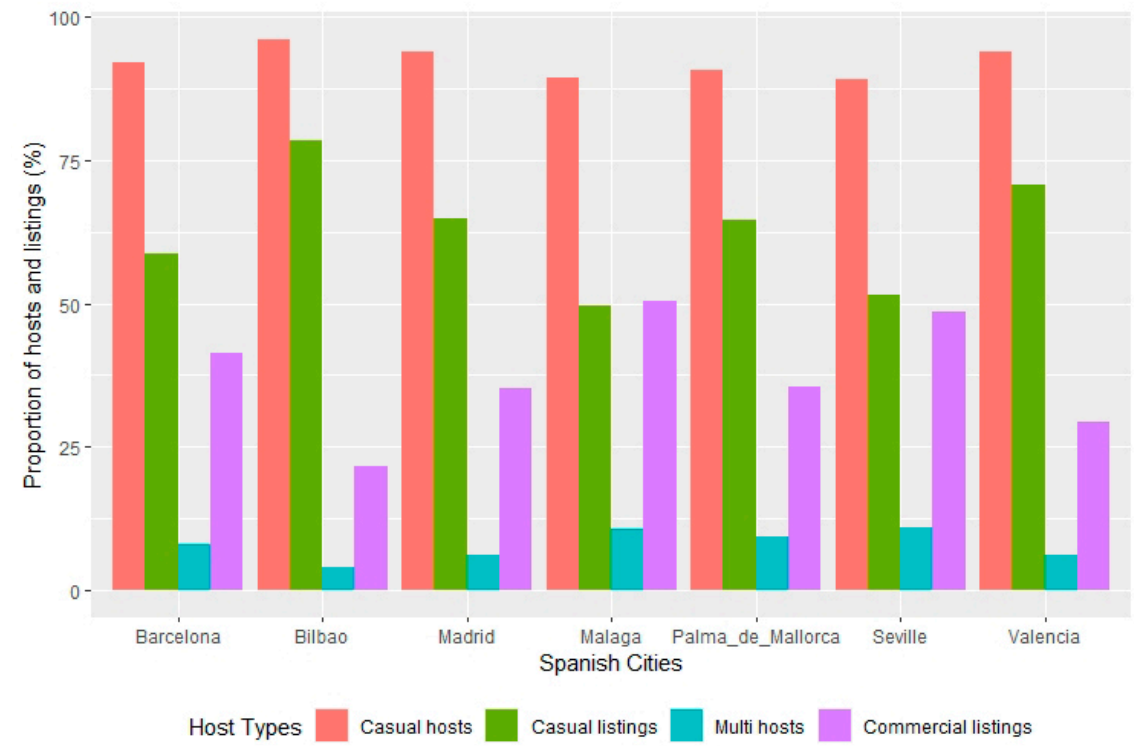

Source: Inside Airbnb.

The peripheral neighbourhoods of San Ignacio, Ibarrekolanda, Arangoiti, Zorroza, Iturrigorri-Peñascal, Santutxu, Otxarkoaga and Bolueta had below 5 listings each. These neighbourhoods form a low-low cluster that surrounds the historic centre of the city.

It is evident from the spatial analysis results that Airbnb listings are concentrated in the central areas of the selected cities. This refutes the claims of the proponents of Airbnb that it brings tourism and business to the peripheral areas of the cities, which are not traditionally visited by tourists. Rather, as we have demonstrated, it concentrates the business of short-term rentals in central neighbourhoods or around the tourist attractions in all selected cities, which already have high disparities between the rich and the poor. In all selected cities, a large number of Airbnb listings are owned by multi-hosts, who rent their entire apartments to tourists to maximize their profits. Seville and Malaga had the highest proportion of multi-hosts, i.e. $11.0 \%$ and $10.7 \%$, who rented $48.4 \%$ and $50.4 \%$ of the total accommodation offered in both cities, respectively. In Barcelona and Madrid, the share of multi-hosts is 7.9\% and $6.1 \%$; however, they rent $41.3 \%$ and $35.2 \%$ of the total listings. Bilbao had the least share of multi-hosts $(3.9 \%)$, who rent $21.5 \%$ of the total listings (Figure 5). This high share of multi-hosts in all selected cities proves the commercialization of Airbnb, which concentrates the revenue earned through Airbnb in fewer hands and lets most of the population in these cities suffer from the adverse consequences of excessive tourism. 


\subsection{Main determinants of the spatial clustering of Airbnb listings}

The first model for the selected cities shows that, in the spatial determinants, the distance to city centre (dist) has a negative impact on the penetration of Airbnb in Barcelona and Bilbao, as expected. However, in all other selected cities it has a positive impact, which means as one moves far from the city centre the number of Airbnb listings increases. The presence of the points of interest ( $p o i)$ for tourists and other short-term visitors has a positive impact on the penetration of Airbnb in all selected cities, except Seville and Palma de Mallorca, where the impact is statistically insignificant. Contrary to my expectation, only Seville witnessed the positive impact of the presence of hotels on the penetration of Airbnb. In all other cities, the presence of hotels does not affect the penetration of Airbnb. Finally, the easy access to public transport services facilitates the spread of Airbnb in Madrid, Valencia, Palma de Mallorca and Bilbao. However, in Barcelona, Seville and Malaga its impact is statistically insignificant. In the demographic determinants, the high population density, contrary to expectations, had a negative impact on the penetration of Airbnb in all selected cities. This can only be explained as being because the supply of spare rooms is lower in the areas with high population density, which reduces the potential growth of Airbnb. The concentration of young people has only shown a statistically significant positive impact on the penetration of Airbnb in Madrid and Bilbao. Similarly, the concentration of native population in some traditional neighbourhoods had a negative impact on the penetration of Airbnb in Barcelona and Malaga. In all other cities its impact is statistically insignificant. Lastly, Madrid, Valencia, Malaga and Bilbao have shown a highly significant positive impact of the concentration of single-person households on the penetration of Airbnb. However, in Barcelona, Seville and Palma de Mallorca its impact is statistically insignificant.

In the socio-economic determinants, in all selected cities except Seville and Palma de Mallorca, any increase in the average household income had a positive impact on the penetration of Airbnb. Similarly, every increase in the house-rent increases the supply of Airbnb accommodation in all selected cities except Palma de Mallorca and Bilbao. In Bilbao, the effect of an increase in house-rent is negative, which means neighbourhoods with high average monthly rents have low penetration of Airbnb. The high proportion of small apartments had a positive impact on the penetration of Airbnb in Madrid, Barcelona, Seville and Malaga. In other cities its impact was statistically insignificant. The high proportion of vacant apartments in Madrid and Barcelona had a positive impact on the spread of Airbnb, while all other cities did not witness any significant impact of vacant apartments. Lastly, the proportion of people who own the house where they live (owners) is expected to have a negative impact on the penetration of Airbnb. From all the selected cities, only Malaga and Palma de Mallorca have a statistically significant negative impact of the high proportion of owners on the penetration of Airbnb. Contrary to the expected results, Barcelona, Seville and Bilbao have registered a positive impact of the high ownership rate on the spread of Airbnb, which means the areas with a high proportion of house own- 
ers have a high number of Airbnb listings. In Madrid and Valencia, its effect is statistically insignificant. In the cultural determinants, the high proportion of people with university education had a statistically significant positive impact on the penetration of Airbnb in all selected cities. In Bilbao and Valencia, the impact is less statistically significant (at 0.1 ) than in other selected cities. The high proportion of migrants from high HDI countries had a positive and statistically significant impact on the penetration of Airbnb in all selected cities, except Barcelona, where its effect is statistically insignificant.

As we have seen in the correlation plots (Figure 3), there are some independent variables that are highly correlated. To avoid the problem of multicollinearity, I have calculated the VIF for each independent variable used in the first models for all selected cities. The highly correlated pairs of variables (with VIF value more than 4) are identified in each first model and one of the variables from the highly correlated pairs is dropped to run the second model. In Madrid, the VIF calculated for each independent variable used in the first model shows that there is high correlation between the variables 'ahincome' and 'education' (VIF of 4); therefore, in the second model, the variable 'ahincome' is dropped. This increases the significance of the variable 'hotel' as a determinant factor, which was not significant in the first model. In Barcelona, high correlation is found between the variables 'houserent' and 'mig' (VIF of 7); therefore, in the second model, the variable 'houserent' is dropped. This increases the significance of the variables 'mig', 'trans' and 'housesize', as determinant factors that positively affect the penetration of Airbnb.

In Valencia and Bilbao, high correlation is found between the variables 'abincome' and 'education' (VIF of 4 and 7); therefore, in the second model for both cities, the variable 'ahincome' is dropped. In Valencia, this increases the significance of the variable 'native', which was not significant in the first model. In addition, it decreases the significance of 'education' as a determining factor that positively affects the penetration of Airbnb in the city. In Bilbao, it increases the statistical significance of the variable 'singleph', which positively impacts the growth of Airbnb. However, it decreases the significance of the variables 'owner' and 'education' as determinant factors. In Seville and Malaga, high correlation is found between the variables 'education' and 'abincome' (VIF of 4 and 4); therefore, in the second model for both cities, the variable 'education' is dropped. In Seville, this increases the significance of the variable 'abincome'. In addition, it decreases the significance of 'housesize' as a determining factor that positively affects the penetration of Airbnb in the city. In Malaga, it increases the significance of the variable 'native' on Airbnb listings. It also increases the significance of the variable 'ahincome' as a determinant factor, which was not significant in the first model. In Palma de Mallorca, high correlation is found between the variables 'mig' and 'native' (VIF of 4); therefore, in the second model, the variable ' $m i g$ ' is dropped. This increases the level of significance for the variables 'popden' and 'native', which have a negative impact on the penetration of Airbnb. It also increases the statistical significance of the variable 'education', which has a positive impact on the growth of Airbnb. 
Table 4. Results of Negative binomial models

\begin{tabular}{|c|c|c|c|c|c|c|c|c|c|c|c|c|c|c|}
\hline \multirow{3}{*}{$\begin{array}{l}\text { Coefficients } \\
\text { (Intercept) }\end{array}$} & \multicolumn{2}{|c|}{ Madrid } & \multicolumn{2}{|c|}{ Barcelona } & \multicolumn{2}{|c|}{ Valencia } & \multicolumn{2}{|c|}{ Seville } & \multicolumn{2}{|c|}{ Malaga } & \multicolumn{2}{|c|}{ Palma de Mallorca } & \multicolumn{2}{|c|}{ Bilbao } \\
\hline & \multicolumn{2}{|c|}{ 1st Model 2nd Model } & \multicolumn{2}{|c|}{ 1st Model 2nd Model } & \multicolumn{2}{|c|}{ 1st Model 2nd Model } & \multirow{2}{*}{\multicolumn{2}{|c|}{$\begin{array}{l}\text { 1st Model 2nd Model } \\
-3.877^{\star \star \star}-4.173^{\star \star \star}\end{array}$}} & \multicolumn{2}{|c|}{ 1st Model 2nd Model } & \multicolumn{2}{|c|}{ 1st Model 2nd Model } & \multicolumn{2}{|c|}{ 1st Model 2nd Mode } \\
\hline & -0.304 & -0.528 & $4.904^{\star \star \star}$ & * $5.720^{\star \star \star *}$ & -1.025 & $-1.309^{\star}$ & & & 1.118 & 1.035 & 0.358 & $2.616^{*}$ & $4.913^{\star \star \star}$ & * $5.010^{\text {*** }}$ \\
\hline \multicolumn{15}{|l|}{ Spatial } \\
\hline dist & $-0.000^{\star \star \star *}$ & $-0.000^{\star \star \star}$ & $-0.001^{\star \star \star}$ & * $-0.001^{\star \star \star}$ & $0.000^{\star \star}$ & $0.000^{\star \star \star}$ & $-0.000^{\star \star \star}$ & $-0.000^{\star \star \star *}$ & $-0.001^{\star \star \star}$ & $-0.001^{\star \star \star}$ & $0.000^{\star \star \star}$ & $0.000^{\star \star \star}$ & $-0.001^{\star \star \star}$ & ${ }^{\star}-0.001^{\star \star \star *}$ \\
\hline poi & $0.007^{\star \star \star}$ & $0.007^{\star \star \star}$ & $0.005^{\star \star \star}$ & $0.006^{\star \star \star}$ & $0.011^{\star \star}$ & $0.009^{\star \star}$ & 0.002 & 0.002 & $0.008^{*}$ & $0.010^{\star \star}$ & -0.002 & 0.002 & $0.007^{\star \star \star}$ & * $0.005^{\star \star \star}$ \\
\hline hotel & 0.032 & 0.041 & -0.024 & -0.020 & 0.037 & 0.028 & $0.087^{\star}$ & $0.085^{\star}$ & -0.144 & -0.124 & -0.121 & -0.117 & -0.024 & -0.031 \\
\hline trans & $0.025^{\star \star \star}$ & $0.022^{\star \star \star}$ & 0.013 & $0.018^{\star}$ & $0.034^{\star \star}$ & $0.032^{*}$ & 0.016 & 0.017 & 0.021 & 0.021 & $0.030^{\star \star}$ & $0.032^{\star \star}$ & $0.041^{*}$ & $0.045^{\star}$ \\
\hline \multicolumn{15}{|l|}{ Demographic } \\
\hline popden & $-0.001^{\star \star \star *}$ & $-0.001^{\star \star \star}$ & $-0.001^{\star \star \star}$ & $-0.001^{\star \star \star}$ & $-0.001^{\star \star}$ & $-0.001^{\star *}$ & $-0.002^{\star \star \star}$ & $-0.002^{\star \star \star *}$ & $-0.002^{\star \star \star \star}$ & $-0.002^{\star \star \star}$ & $-0.001^{\star}$ & $-0.002^{\star \star \star}$ & $-0.002^{\star \star \star}$ & ${ }^{\star}-0.001^{\star \star \star *}$ \\
\hline young & $0.046^{\star \star \star}$ & $0.052^{\star \star \star}$ & 0.000 & -0.003 & 0.009 & 0.012 & -0.006 & -0.008 & 0.014 & 0.003 & 0.024 & 0.015 & $0.061^{\star \star}$ & $0.067^{\star \star}$ \\
\hline native & 0.002 & -0.001 & $-0.024^{\star \star \star}$ & $-0.022^{\star \star \star}$ & -0.005 & -0.010 & 0.008 & 0.006 & -0.016 & $-0.018^{\star}$ & -0.005 & $-0.036^{\star \star \star}$ & 0.015 & 0.008 \\
\hline singleph & $0.007^{\star \star \star}$ & $0.009^{\star \star \star}$ & 0.001 & 0.002 & $0.008^{\star \star}$ & $0.010^{\star \star}$ & 0.000 & 0.003 & $0.014^{\star \star}$ & $0.017^{\star \star \star}$ & 0.003 & 0.004 & 0.010 & $0.016^{\star \star}$ \\
\hline \multicolumn{15}{|l|}{ Socioeconomic } \\
\hline ahincome & $0.000^{\star \star \star}$ & & $0.000^{\star \star \star}$ & * $0.000^{\star \star \star \star}$ & $0.000^{\star \star \star}$ & & 0.000 & $0.000^{*}$ & 0.000 & $0.000^{\star}$ & $0.000^{\star *}$ & $0.000^{\star \star}$ & $0.000^{\star}$ & \\
\hline houserent & $0.080^{\star \star \star}$ & $0.070^{\star \star \star}$ & $0.057^{\star \star \star}$ & & 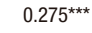 & $0.274^{\star \star \star}$ & $0.578^{\star \star \star}$ & $0.628^{\star \star \star}$ & $0.190^{\star \star \star}$ & $0.207^{\star \star \star}$ & -0.028 & 0.003 & $-0.338^{\star \star \star}$ & ${ }^{\star}-0.402^{\star \star \star}$ \\
\hline housesize & $0.006^{\star \star \star}$ & $0.007^{\star \star \star}$ & 0.003 . & $0.003^{\star}$ & -0.001 & 0.000 & 0.005 & 0.004 & $0.013^{\star \star}$ & $0.012^{\star \star}$ & -0.003 & 0.003 & -0.004 & -0.002 \\
\hline vachouse & $0.005^{\star}$ & $0.005^{\star}$ & 0.004 & 0.004 & -0.003 & -0.003 & 0.004 & 0.004 & 0.005 & 0.008 & 0.006 & 0.012 & 0.006 & 0.007 \\
\hline owner & 0.000 & 0.000 & 0.003 & 0.003 & -0.001 & -0.001 & $0.007^{\star}$ & $0.006^{*}$ & $-0.015^{\star \star \star}$ & $-0.015^{\star \star \star}$ & $-0.014^{\star \star \star}$ & $-0.017^{\star \star \star}$ & 0.006 . & 0.006 \\
\hline \multicolumn{15}{|l|}{ Cultural } \\
\hline education & $0.017^{\star \star \star}$ & $0.009^{\star \star \star}$ & $0.006^{\star}$ & $0.005^{\star}$ & $0.014^{\star \star \star}$ & 0.005 & $0.016^{\star \star}$ & & $0.027^{\star \star \star}$ & & $0.016^{\star}$ & $0.027^{\star \star \star}$ & 0.013 & 0.007 \\
\hline mig & $0.110^{\star \star \star}$ & $0.105^{\star \star \star}$ & 0.014 & $0.033^{\star \star \star}$ & $0.119^{\star \star \star}$ & $0.136^{\star \star \star}$ & $0.385^{\star \star \star}$ & $0.409^{\star \star \star}$ & $0.274^{\star \star \star}$ & $0.293^{\star \star \star}$ & $0.113^{\star \star \star}$ & & $0.181^{\star *}$ & $0.190^{\star \star}$ \\
\hline \multicolumn{15}{|l|}{$\begin{array}{l}\text { Goodness of } \\
\text { fit indicators }\end{array}$} \\
\hline AIC & 12296.0 & 12338.7 & 6749.9 & $\begin{array}{ll}9 & 6777.8\end{array}$ & 3678.5 & 3688.5 & 2474.4 & $4 \quad 2481.4$ & 2500.9 & $\begin{array}{l}9 \\
9\end{array}$ & 1332.1 & 1354.9 & 1193.0 & $\begin{array}{ll}0 & 1197.2\end{array}$ \\
\hline BIC & 12394.6 & 12431.5 & 6834.5 & $5 \quad 6857.3$ & 3753.0 & 3758.6 & 2547.1 & 2549.8 & 2570.2 & 2575.3 & 1392.1 & 1411.4 & 1254.6 & $\begin{array}{ll}6 & 1255.2\end{array}$ \\
\hline Log-Likelihood & -6131.0 & -6153.3 & -3358.0 & $\begin{array}{ll}0 & -3372.9\end{array}$ & -1822.3 & -1828.3 & -1220.2 & $\begin{array}{ll}2 & -1224.7\end{array}$ & -1233.5 & $5-1239.1$ & -649.0 & -661.5 & -579.5 & $\begin{array}{ll}5 & -582.6\end{array}$ \\
\hline
\end{tabular}

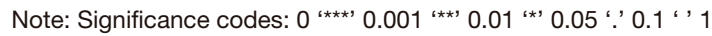

Source: Compiled by author.

The AIC, BIC and the Log-Likelihood values of both models show a significant improvement in the goodness of fit of the second model, which justifies the dropping of one variable from the pairs of highly correlated independent variables (Table 4).

\section{Concluding remarks}

In this paper, I measured the extent of spatial penetration of Airbnb in the seven main tourist cities of Spain and the factors that determine it. The result of the spatial analysis demonstrates that the majority of Airbnb listings are concentrated in the central parts of the selected cities. These central areas are traditionally known for their high tourism potential, and always 
remained favourite destinations for national and international tourists. This refutes the claim of Airbnb proponents that it brings tourism to the peripheral neighbourhoods of cities, which traditionally do not receive tourists. The regression models used in the study show that the concentration of the points of attraction for tourists and other short-term visitors, low population density, big houses, large proportion of single-person households, high house-rent, high average household income, a large proportion of university educated people and a high share of immigrants from high HDI countries have a positive impact on the penetration of Airbnb in the residential areas of the selected cities.

The presence of a high number of multi-hosts in the selected cities confirms the commercialization of the Airbnb service, which accumulates the benefits of the service in the hands of some commercial users. Currently, in all selected cities a significant number of Airbnb hosts are not ordinary people who rent a spare room to supplement their income, but profiteering landlords who rent whole apartments or entire apartment blocks. This contradicts the stated mission of Airbnb that it empowers small house-owners to benefit from their properties by leasing their unused rooms or second houses. Rather, it displaces the local population from their traditional working-class neighbourhoods by increasing long-term rents and occupying the already scarce stock of houses from the long-term rentals market.

Airbnb also contributes to growing spatial inequalities in selected cities by concentrating income earned in the form of rent or profit made by local businessmen from tourism in specific neighbourhoods. The benefits of Airbnb do not reach the socio-economically marginalized and vulnerable neighbourhoods in any of the selected cities. These neighbourhoods do not receive any increase in tourism; in addition, they suffer the ill effects of the touristification of their local businesses, urban centres and public services. Airbnb has also affected the lives of ordinary citizens by transforming their homes into commercial assets that can be rented to strangers for additional income. It contributes to the loss of the sense of neighbourhood or attachment to the neighbourhood among natives and commercializes every inch of urban space, which in turn destroys community life in large cities. The high presence of tourists in residential areas increases congestion and competition for already scarce public spaces and services in all selected cities.

All these results point to an urgent need for Airbnb regularization to make it a spatially just service and reduce its impact on community life in all selected cities. In this respect, steps should be taken such as: the maximum short-term rental quota should be fixed for each neighbourhood based on the availability of other services and the capacity of the existing public infrastructure. Small homeowners in peripheral neighbourhoods should be allowed to rent their spare rooms; however, multi-hosts in city centres should be restricted to particular seasons. A rent limit for long-term rentals should be imposed to control the speculative increase in house-rents and no new licences should be issued for short-term rentals in the central neighbourhoods of selected cities. 
Long-term tenants must be safeguarded by law and it should be made difficult for the house-owner to evacuate people from their long-term rentals after completion of their rent-contracts. All housing units, which are on the long-term rental market, should be forced to remain so. Among the selected cities, the local governments in Barcelona (2015), Madrid (2018) and Valencia (2019) have already taken measures to control the penetration of Airbnb in the central areas and extend it to the peripheral neighbourhoods. In Palma de Mallorca a complete ban has been imposed on renting apartments to tourists in residential areas.

The recent COVID-19 pandemic has adversely affected the spread of Airbnb in all selected cities due to travel restrictions. However, it has the potential to bounce back when an effective vaccine is available to everyone. In the future, it will be interesting to see how the restrictions imposed by the local governments affect the penetration of Airbnb in different parts of the selected cities and how Airbnb becomes a more spatially just service that, in addition to multi-hosts, also benefits the small homeowners living in the marginalized peripheral neighbourhoods of the selected cities.

\section{Bibliographical references}

ABDAR, M. and YEN, N.Y. (2017). "Understanding regional characteristics through crowd preference and confidence mining in P2P accommodation rental service". Library Hi Tech, 35 (4), 521-541. $<$ https://doi.org/10.1108/LHT-01-2017-0030>

ADAMiAK, C. (2018). "Mapping Airbnb supply in European cities". Annals of Tourism Research, 71 (2), 67-71. $<$ https://doi. org/10.1016/j.annals.2018.02.008>

Adamiak, C.; Szyda, B.; Dubownik, A. and García-Álvarez, D. (2019). "Airbnb offer in Spain- spatial analysis of the pattern and determinants of its distribution". ISPRS International Journal of Geo-Information, 8 (3), 155-186. $<$ https://doi.org/10.3390/ijgi8030155>

Airbnb (2019). "About Us". About Airbnb Website. Retrieved from <https://www. Airbnb.com/about/about-us. Accessed October 20, 2019>.

ANSELIN, L. (1995). "Local indicators of spatial association-LISA". Geographical Analysis, 27 (2), 93-115. <https://doi.org/10.1111/j.1538-4632.1995.tb00338.x>

Arias Sans, A. and Quaglieri Dominguez, A. (2016). "Unravelling Airbnb: Urban perspectives from Barcelona”. In: Russo, A.P. and RicharDS, G. (eds.). Reinventing the Local in Tourism: Producing, Consuming and Negotiating Place. Bristol, UK: Channel View Publications, 209-228.

BlázQuez-Salom, M.; Blanco-Romero, A.; Guall, J. and Murray, I. (2019). "Tourist gentrification of retail shops in Palma (Majorca)". In: Milano, C.; CHeER, J. M. and Novelli, M. (eds.). Over tourism: Excesses, Discontents and Measures in Travel and Tourism. London, UK: CABI Publishing, 39-69.

Boros, L.; DudÁs, G.; KovalcsiK, T.; PApp, S. and Vida, G. (2018). “Airbnb in Budapest: analysing spatial patterns and room rates of hotels and peer-to-peer accomodations". GeoJournal of Tourism and Geosites, 21 (1), 26-38. 
Bulchand-Gidumal, J.; Melian-Gonzalez, S. and lópez-Valcarcel, B. G. (2019). "Is the sharing economy for all? An answer based on neighbourhoods, types of hosts, and user complaints". In: PESONEN, J. and NeIDHARDT, J. (eds.). Information and communication technologies in tourism. Cham: Springer, 55-66.

<https://doi.org/10.1007/978-3-030-05940-8_5>

Cameron, A.C.; Trivedi, P.K. (1998). Regression Analysis of Count Data. Cambridge University Press, Cambridge.

- (2005). Micro econometrics: Methods and Applications. Cambridge: Cambridge University Press.

Cesarani, M. and Nechita, F. (2017). "Tourism and the sharing economy. Evidence from Airbnb usage in Italy and Romania”. Symphonya: Emerging Issues in Management, 3 (1), 32-47. $<$ https://doi.org/10.4468/2017.3.04cesarani.nechita>

Choi, K.-H.; Joohyun, J.; Su Yeol, R.; Su-Do, K. and Seong-Min, Y. (2015). "The relationship between Airbnb and the hotel revenue: in the case of Korea”. Indian Journal of Science and Technology, 8 (26). <https://doi.org/10.17485/ijst/2015/v8i26/81013>

Cócola Gant, A. (2016). "Holiday Rentals: The New Gentrification Battlefront". Sociological Research Online, 21 (3), 10. <https://doi.org/10.5153/sro.4071>

Cócola Gant, A. and Gago, A. (2019). "Airbnb, buy-to-let investment and tourismdriven displacement. A case study in Lisbon". Environment and Planning A: Economy and Space. Online August 2019. <https://doi.org/10.1177/0308518X19869012>

Dogru, T.; Mody, M. and Suess, C. (2018). "Adding evidence to the debate: quantifying Airbnb's disruptive impact on ten key hotel markets”. Tourism Management, 72 (1), 27-38. <https://doi.org/10.1016/j.tourman.2018.11.008>

Domènech, A.; Larpin, B.; SCHegG, R. and Scaglione, M. (2019). "Disentangling the geographical logic of Airbnb in Switzerland”. Erdkunde, 73 (4), 245-258.

DudAS, G.; VIDA, G.; KOVAlcsiK, T. and Boros, L. (2017). "A socio-economic analysis of Airbnb in New York City”. Regional Studies, 7 (1), 135-151. <https://doi.org/10.15196/RS07108>

Eugenio-Martin, J.L.; Cazorla-Artiles, J.M. and GonZalez-Martel, C. (2019). "On the determinants of Airbnb location and its spatial distribution". Tourism Economics, 25 (8), 1224-1244. <https://doi. org/10.1177/1354816618825415>

FLORIDA, R. (2002). "Bohemia and economic geography". Journal of Economic Geography, 2 (1), 55-71.

ForNo, F. and GARIBALDI, R. (2015). "Sharing economy in travel and tourism: The case of home-swapping in Italy". Journal of Quality Assurance in Hospitality \& Tourism, 16 (2), 202-220.

Fraiberger, S.P. and Sundararajan, A. (2015). "Peer-to-peer rental markets in the sharing economy”. NYU Stern School of Business Research Paper (First version March 2015; current version September 2017). <http://dx.doi.org/10.2139/ssrn.2574337>

Fuentes, R. and NAVARRETE, L. (2019). "Tourists in hotels versus holiday homes: Economic impact and characterization”. Tourism Review Int., 20 (1), 177-195. 
Garcia-López, M.-À.; Jofre-Monseny, J.; Martínez Mazza, R. and Segú, M. (2019). "Do short-term rental platforms affect the housing market? Evidence from Airbnb in Barcelona”. IEB Working Paper, 2019/05. <http://dx.doi.org/10.2139/ssrn.3428237>

Gil, J. and Sequera, J. (2018). "Expansión de la ciudad turística y nuevas resistencias. El caso de Airbnb en Madrid [The expansion of the tourist city and new resistances. The case of Airbnb in Madrid]". EMPIRIA. Revista de Metodología de Ciencias Sociales, 41, 15-32. <https://doi.org/10.5944/empiria.41.2018.22602>

Gravari-Barbas, M. and GuinAND, S. (2017). "Addressing tourism-gentrification processes in contemporary metropolises”. In: GraVARI-BARBAS, M. and GUINAND, S. (eds.). Tourism and Gentrification in Contemporary Metropolises: International Perspectives. London: Routledge, 1-21. <https://doi.org/10.4324/9781315629759>

GunTeR, U. (2018). "What makes an Airbnb host a superhost? Empirical evidence from San Francisco and the Bay Area". Tourism Management, 66, 26-37. <https://doi.org/10.1016/j.tourman.2017.11.003>

GunTER, U. and ÖNDER, I. (2017). "Determinants of Airbnb demand in Vienna and their implications for the traditional accommodation industry". Tourism Economics, 24 (3), 270-293. <https://doi.org/10.1177/1354816617731196>

Gutiérrez, J.; García-Palomares, J.C.; Romanillos, G. and Sales-Olmeda, M.H. (2017). "The eruption of Airbnb in tourist cities: Comparing spatial patterns of hotel and peer-to-peer accommodations in Barcelona". Tourism Management, 62 (1), 278-291.

GutTentag, D. (2015). “Airbnb: Disruptive innovation and the rise of an informal tourism accommodation sector". Current Issues in Tourism, 18 (12), 1192-1217. <https://doi.org/10.1080/13683500.2013.827159>

HeO, C.Y.; Blal, I. and Choi, M. (2019). "What is happening in Paris? Airbnb, hotels, and the Parisian market: a case study". Tourism Management, 70 (1), 78-88. <https://doi.org/10.1016/j.tourman.2018.04.003>

Horn, K. and Merante, M. (2017). "Is home sharing driving up rents? Evidence from Airbnb in Boston". Journal of Housing Economics, 38 (C), 14-24. <https://doi.org/10.1016/j. jhe.2017.08.002>

IoAnnides, D.; Roslmaier, M. and van Der Zee, E. (2018). "Airbnb as an instigator of tourism bubble expansion in Utrecht's Lombok neighbourhood”. Tourism Geographies, 21 (5), 822-840. <https://doi.org/10.1080/14616688.2018.1454505>

Larpin, B.; Mabillard, J.; Scaglione, M.; Favre, P. and SchegG, R. (2019). “An analysis of regional developments of Airbnb in Switzerland: insights into growth patterns of a P2P platform". In: PESONEN, J. and NeIDHARDT, J. (eds.). Information and communication technologies in tourism. Cham: Springers, 92-103. <https://doi.org/10.1007/978-3-030-05940-8_8>

LESTEGẤS, I.; SEIXAS, J. and LoIS-GonZÁLEZ, R.C. (2019). "Commodifying Lisbon: A Study on the Spatial Concentration of Short-Term Rentals”. Social Sciences, 8 (33), 1-15. <https://doi.org/10.3390/socsci8020033>

LEE, D. (2016). "How Airbnb Short-Term Rentals Exacerbate Los Angeles's Affordable Housing Crisis: Analysis and Policy Recommendations". Harvard Law \&. Policy Review, 10, 229-253. 
McCullagh, P. and Nelder J. A. (1989). Generalized Linear Models. 2nd edition. London: Chapman \& Hall.

Mínguez, C.; Piñeira, M.J. and Fernández-Tabales, A. (2019). "Social Vulnerability and Touristification of Historic Centers”. Sustainability, 11 (16), 44-78

Molla, R. (2019). "American consumers spent more on Airbnb than on Hilton last year". Accessed on 21/10/2019. Retrieved from <https://www.vox. com/2019/3/25/18276296/airbnb-hotels-hilton-marriott-us-spending>.

Novy, J. (2017). "The selling (out) of Berlin and the de- and re-politicization of urban tourism in Europe's Capital of Cool”. In: ColOmb, C. and Novy, J. (eds.). Protest and resistance in the tourist. London: Routledge, 52-72.

OsKam, J. and BoswiJk, A. (2016). "Airbnb: the future of networked hospitality businesses”. Journal of Tourism Futures, 2 (1), 22-42. $<$ https://doi.org/10.1108/JTF-11-2015-0048>

PAN, Y. and JACKSON, R. T. (2008). "Ethnic difference in the relationship between acute inflammation and serum ferritin in US adult males". Epidemiology and Infection, 136 (3), 421-431.

Quattrone, G.; Greatorex, A.; Quercia, D.; Capra, L. and Musolesi, M. (2018). "Analysing and predicting the spatial penetration of Airbnb in U.S. cities". EPJ Data Science, 7 (31), 1-24. <https://doi.org/10.1140/epjds/s13688-018-0156-6>

Quattrone, G.; Proserpio, D.; Quercia, D.; Capra, L. and Musolesi, M. (2016). "Who Benefits from the "Sharing" Economy of Airbnb?" In: Bourdeau, J.; Hendler, J.; Nkambou, R.; Horrocks, I. and Zhao, BY. (eds.). WWW 2016: 25th International World Wide Web Conference Montreal, Canada, April 11 - 15, 2016. (pp. 1385-1394). International World Wide Web Conferences Steering Committee Republic and Canton of Geneva: Geneva, Switzerland.

Roelofsen, M. (2018). "Exploring the socio-spatial inequalities of Airbnb in Sofia, Bulgaria”. Erdkunde, 72 (4), 312-327. <https://doi.org/10.3112/erdkunde.2018.04.04>

Rogerson, P. (2001). Statistical methods for geography. Thousand Oaks: Sage.

SAMAAN, R. (2015). "Airbnb, Rising Rent, and the Housing Crisis in Los Angeles". Policy report prepared for the Los Angeles Alliance for a New Economy.

Strommen-BaKhtiar, A. and Vinogradov, E. (2019). "The adoption and development of Airbnb services in Norway". International Journal of Innovation and Digital Economy, 10 (1), 28-39. <https://doi.org/10.4018/IJIDE.2019040102>

Tobler, A.W.R. (1970). "A computer movie simulating urban growth in the Detroit region”. Economic Geography, 46 (Sup1), 234-240. <https://doi.org/10.2307/143141>

Varma, A.; Jukic, N.; Pestek, A.; Shultz, C.J. and Nestorov, S. (2016). “Airbnb: exciting innovation or passing fad?”. Tourism Management Perspectives, 20, 228-237. <https://doi.org/10.1016/j.tmp.2016.09.002>

Wachsmuth, D.; Kerrigan, D.; Chaney, D. and Shillolo, A. (2017). "Short-term Cities: Airbnb's Impact on Canadian Housing Markets”. Policy report. Urban Politics and Governance research group, School of Urban Planning, McGill University. Retrieved from <https:/upgo.lab.mcgill.ca/publication/short-term-cities/ short-term-cities.pdf>. 
Wachsmuth, D. and Weisler, A. (2018). "Airbnb and the Rent Gap: Gentrification Through the Sharing Economy". Environment and Planning A: Economy and Space, 50 (6), 1147-1170. <https://doi.org/10.1177/0308518X18778038>

WieditZ, T. (2017). "Squeezed Out: Airbnb’s Commercialization of Home-Sharing in Toronto". Policy report prepared for FAIRBNB.CA Coalition.

YrigoY, I. (2017). “Airbnb en Menorca: ¿¿Una nueva forma de gentrificación turística?: Localización de la vivienda turística, agentes e impactos sobre el alquiler residencial”. Scripta Nova Revista Electrónica de Geografia y Ciencias Sociales, 21 (580). $<$ https://doi.org/10.1344/sn2017.21.18573>

- (2019). "Rent gap reloaded: Airbnb and the shift from residential to touristic rental housing in the Palma Old Quarter in Mallorca, Spain”. Urban Studies, 56 (13), 2709-2726. <https://doi.org/10.1177/0042098018803261>

Zervas, G.; Proserpio, D. and Byers, J.W. (2014). "The Rise of the Sharing Economy: Estimating the Impact of Airbnb on the Hotel Industry". Boston University School of Management Research Paper No. 2013-16. Retrieved from <http:// people.bu.edu/zg/publications/airbnb.pdf $>$. 